\title{
BIOGENIC SYNTHESIS OF NANOSILVER PARTICLES FROM ROOT EXTRACT OF MORUS ALBA L. AND THEIR BIOLOGICAL ACTIVITIES
}

\author{
GHAZALA FARID MINHAS ${ }^{1}$, BUSHRA HAFEEZ KIANI ${ }^{2 *}$, UZMA GHANI ${ }^{1}$, KHAWAJA \\ SHAFIQUE AHMAD ${ }^{3}$, AALIA SHAH ${ }^{1}$
}

${ }^{I}$ Department of Biotechnology, Women University of Azad Kashmir, Bagh, AJK, Pakistan

${ }^{2}$ Department of Biological Sciences, International Islamic University, Islamabad (44000), Pakistan

${ }^{3}$ Department of Botany, Department of Botany, University of Poonch Rawalakot (AJ\&K), Pakistan

*corresponding author: bushra.hafeez@iiu.edu.pk

Manuscript received: February 2020

\begin{abstract}
Morus alba (Moraceae), mulberry, is considered a great source of therapeutic agents for the treatment of chronic diseases like cancer, high blood pressure, high cholesterol and ulcer. The present study reported the simple and successful synthesis of silver nanoparticles by using aqueous, ethanol and methanol root extracts of $M$. alba and the analysis of their efficacy against different biological activities. UV-Vis spectroscopy, X-Ray diffraction (XRD) and scanning electron microscopy (SEM) techniques were used to characterize the morphology of silver nanoparticles. Brine shrimp cytotoxicity, antioxidant, antibacterial, antifungal, antitumour assays were performed and free radical scavenging activity was measured using the DPPH free radical assay. The nanoparticles were characterized by UV-Vis and XRD, UV-Vis spectra showed the characteristic peaks ranging from $400-800 \mathrm{~nm}$. With the help of SEM analysis, the size of silver nanoparticle was found to be $297 \mathrm{~nm}$ and their shape was irregular and had a rough surface. Among all the extracts, methanolic extracts showed strong antibacterial activity $(\mathrm{MIC}=0.5)$, antifungal activity (MIC $=0.5$ ), with MIC value of 0.5 as compared to ethanolic extract $(\mathrm{MIC}=5)$ and aqueous extracts $(\mathrm{MIC}=10)$. Methanolic extracts also showed the highest antioxidant activity $\left(\mathrm{IC}_{50}=158.68\right)$, antitumour activity $\left(\mathrm{IC}_{50}=105.03\right)$, and cytotoxicity activities $\left(\mathrm{IC}_{50}=24.83\right.$ ) as compared to other extracts. These results suggest that secondary metabolites in the root extracts of M. alba may be responsible for enhanced biological activities. Nanoparticles synthesized by employing plants can have advantages over other biological entities which can overcome time consuming processes and be environmentally friendly.
\end{abstract}

\section{Rezumat}

Morus alba (Moraceae) este considerat o sursă de compuși biologic activi pentru bolile cronice precum cancerul, hipertensiunea arterială și ulcerul. Studiul prezintă sinteza nanoparticulelor de argint prin utilizarea extractelor apoase, etanolice și metanolice din rădăcină de $M$. alba și analiza activității biologice a acestora. Pentru a caracteriza morfologia nanoparticulelor de argint sau folosit tehnici de spectroscopie UV-Vis, difracție cu raze X (XRD) și microscopie electronică cu scanare (SEM). S-au efectuat teste de citotoxicitate, teste privind acțiunea antioxidantă, antibacterienă, antifungică, antitumorală și de scavenger. Spectrele UV-Vis au arătat variații ale nanoparticulelor între 400 și $800 \mathrm{~nm}$. Cu ajutorul analizei SEM, s-a constatat că dimensiunea nanoparticulelor de argint este de $297 \mathrm{~nm}$, cu formă neregulată şi suprafaţă rugoasă. Extractele metanolice au prezentat activitate antibacteriană și antifungică puternică. De asemenea extractele metanolice au prezentat, cea mai potentă activitate antioxidantă, antitumorală și citotoxică.

Keywords: Morus alba, silver nanoparticle, biological activities, cancer, secondary metabolites

\section{Introduction}

Plants have always been a part of our lives being used for various medicinal purposes since ancient times. Plants are nature's "chemical factories". They are cost efficient and require low maintenance. Researchers have recognized different plant based compounds that are extensively used in various medicines [1]. In developing countries like Pakistan, around 3.3 billion people are using medicinal plants on a regular basis to cure various ailments [2]. Root bark of Morus alba (mulberry) is widely used as a medicine in China since 659 A.D. and Chinese pharmacopoeia listed its root bark, leaves, fruits, and stem as a constituent in drugs preparations [3], and it is an official drug of the British Herbal pharmacopoeia [4]. The root bark has anti-helminthic properties and root juice has coagulation effects. Albanol A isolated from the root bark has been proven as an effective medicine to cure leukaemia [5]. Root bark has also been used in herbal medicine as anti-chloristic, anti-cough, liver and kidney protective agent, diuretic, hypotensive and analgesic. Roots are a rich source of amino acids, carbohydrates, triterpenes, proteins and vitamins $C$ [6]. Plants provide a great area for synthesis of nanoparticles, free from toxic chemicals and have the ability of copping naturally. Silver nanoparticles are using 
silver in range of $1 \mathrm{~nm}$ and $100 \mathrm{~nm}$ in size. The desired structure and size is achieved by controlling parameters [8]. In commercial products silver nanoparticles are in the range of 5 to $50 \mathrm{~nm}$ [1].

Nanotechnology is a common word these days, but many of us do not realize its amazing impact on our daily lives. The implications of nanotechnology are wide-ranging and could include medicine, military applications, computing and astronomy [9]. The science of nanotechnology is developing new commercial applications in the pharmaceutical industry including advanced drug delivery systems, new therapies, optoelectronics and in-vivo imaging. Nanotechnology is designed to provide a novel and improved approach to cancer diagnosis and treatment $[10,11]$.

Silver nanoparticles exhibit new and improved properties according to their distribution, size and morphology [12]. Silver nanoparticles are mostly used due to their unique properties in biosensing, photonics, electronics, chemical sensing, catalysis, optics, antimicrobials, biomaterial and pharmaceutical sector [1], which can be incorporated into composite fibres, cosmetic products, cryogenic superconducting materials, electronic components and food industry $[13,14]$. Silver nanoparticles can be synthesized by different methods such as electro-chemicals [12], biological techniques [15], radiation [16], physical and phytochemicals method [17]. Physicochemical methods of silver nanoparticles synthesis use high temperature, pressure, toxic chemicals and produces hazardous byproducts. Therefore it is important to explore safe processes for the synthesis of silver nanoparticles as biodegradable polymers, micro-organisms or plant extracts $[18,19]$.

The green synthesis of nanoparticles has been proposed as a cost-effective and environmentally friendly alternative to chemical and physical methods. Plantmediated synthesis of nanoparticles is a green chemical approach that connects nanotechnology with plants [19]. Novel methods of ideally synthesizing nanoparticles (NPs) are formed at ambient temperatures, neutral $\mathrm{pH}$, low costs and being environmentally friendly. Keeping these goals in view, nanomaterials have been synthesized using various routes. Among the biological alternatives, plants and plant extracts seem to be the best option [20].

Biosynthesis of silver nanoparticles from several plants like Solanum torvum [20], Euphorbia hitra [17] and Coriandrum sativum [21] has been reported. Plants have advantages over other biological entities for the synthesis of nanoparticles because overcome the time consuming method of employing microbes and also maintaining their culture which can lose their potential towards synthesis of nanoparticles [13]. The roots of $M$. alba have been widely used in healthcare for curing depression, dementia, nephrotoxicity, Parkinson's disease and as a skin whitening agent [22], and are cheap and simple source for the treatment of cancer by reducing the invasiveness of cancerous cells [23]. Therefore, in this context, the present study was designed to synthesize silver nanoparticles (AgNPs) from the root bark of $M$. alba and their efficacy was analysed against different biological activities.

\section{Materials and Methods}

\section{Study Area}

The present research work was carried out in the Department of Biotechnology, Women University of Azad Kashmir, Bagh, Pakistan, in collaboration with Nano-Science and Technology Department, National Centre for Physics Quaid-i-Azam University Islamabad, Pakistan. The plant material (Morus alba) was collected from different areas of Bagh Azad Kashmir, Pakistan, and was confirmed by an expert taxonomist from the Department of Plant Sciences, Quaid-i-Azam University, Islamabad, Pakistan, the plant being registered with voucher number WUB-T-174 in the herbarium.

\section{Chemicals}

All the chemicals used in the experimental work were of the highest grade of purity. Chemicals were purchased from Sigma Chemical Co, USA, and E. Merck, Germany.

Preparation of plant extracts

Extracts of shade dried roots of $M$. alba were prepared by simple maceration. The plant material i.e. roots (100 g) was grounded and soaked in $200 \mathrm{~mL}$ of methanol, ethanol and aqueous solvent separately for 7 days at room temperature $\left(25^{\circ} \mathrm{C} \pm 2^{\circ} \mathrm{C}\right)$ by occasional soaking and filtered through Whatman filter paper. The filtrate was concentrated in a rotary evaporator (Rotavapor $\mathrm{R}-200$, Buchi) and finally dried at $45^{\circ} \mathrm{C}$ in vacuum oven (Vacucell, Einrichtungen $\mathrm{GmbH}$ ) to obtain the crude extract. The extract weight was calculated and stored at $4^{\circ} \mathrm{C}$ for further analysis (Table I).

Green synthesis of silver nanoparticles

Silver nitrate $\left(\mathrm{AgNO}_{3}\right)$ (Sigma-Aldrich) was used as a precursor salt for the synthesis of the silver nanoparticles.

Table I

Extracts of roots of Morus alba using three different solvents

\begin{tabular}{ccccc}
\hline Sample name & Solvent & Weight of sample $(\mathrm{g})$ & Solvent added $(\mathbf{m L})$ & Extract weight $(\mathbf{m g})$ \\
\hline \multirow{3}{*}{ Roots } & Methanol & 100 & 1250 & 1250 \\
& Ethanol & 100 & 1460 & 1460 \\
& Aqueous & 100 & 1070 & 1070 \\
\hline
\end{tabular}

For the synthesis of AgNPs $50 \mathrm{mM}$ stock solution of $\mathrm{AgNO}_{3}$ was used. $100 \mathrm{~mL}$ aqueous solution of silver nitrate was prepared in Erlenmeyer flask. Then 1.0, 2.0, 3.0, 4.0 and $5.0 \mathrm{~mL}$ of root extract prepared in 
methanol, ethanol and aqueous was added separately to $10 \mathrm{~mL}$ aqueous silver nitrate solution and stirred continuously. The solution was kept in a dark chamber for 3 days until the solution colour changed to yellow or dark yellow. After three days, the solution turns yellow to yellow-red or dark brown indicating the formation of silver nanoparticles. The solution was filtered and monitored by periodic sampling by the $\mathrm{UV}-\mathrm{V}$ is spectrophotometer.

$U V$-Vis spectroscopy

The bio-reduction of silver nitrate $\mathrm{AgNO}_{3}$ to silver nanoparticles (AgNPs) was monitored periodically by UV-Vis spectroscopy (Perkin-Elmer Lambda-25 spectrophotometer) after the dilution of the samples. The UV-Vis spectrometric determinations were made between 200 and $800 \mathrm{~nm}$ against water as reference $[4,21]$.

$X$-ray diffraction

Freeze dried powders of the synthesized silver nanoparticles from the root extracts of $M$. alba (methanol, ethanol and aqueous) were used for x-ray diffraction analysis. Crystalline metallic silver nanoparticles were examined using XRD (Brukar D8 advance).

Scanning Electron Microscopy Analysis (SEM)

SEM analysis was used to check the morphology of nanoparticles as well as their size from the nanometer to micrometer scale. Silver nanoparticles were analysed by placing a drop of sample suspension over carbon coated grid and after drying it was examined and photographed in SEM at CAEPE (Centre for Advanced Electronics and Photovoltaic Engineering), International Islamic University Islamabad, Pakistan.

Biological activities

Following, biological activities assessments were performed on the nanoparticles of root extracts of M. alba.

Brine shrimp cytotoxicity assay. Brine shrimp cytotoxicity assay was performed according to the methodology presented in literature [24]. Brine shrimp (Artemia salina) larvae, used as test organisms, hatched at $37^{\circ} \mathrm{C}$ in artificial sea water. To a $20 \mathrm{~mL}$ glass vial, $0.5 \mathrm{~mL}$ sample of extracts was added to have final concentration of 1000, 100 and $10 \mu \mathrm{g} / \mathrm{mL}$. The solvent from each vial was evaporated, followed by the addition of $2 \mathrm{~mL}$ of artificial seawater. 10 shrimps were transferred into each vial and the final volume was adjusted to 5 $\mathrm{mL}$ and kept under fluorescence light at $37^{\circ} \mathrm{C}$ for $24 \mathrm{~h}$. The test was performed in triplicate and survivors were counted by using a magnifying glass and a Pasteur pipette. Percentage death was calculated (by Abbott's formula). $\mathrm{LD}_{50}$ values were determined by Finney computer program [25].

Antibacterial assay. The antibacterial assay was performed by disc diffusion method by following the methodology of Chan YSS et al. [26]. The antibacterial activity was tested against five bacterial strains; three were gram positive i.e. Staphylococcus aureus (ATCC 6538), Bacillus subtilis (ATCC 6633) and Micrococcus luteus (ATCC 10240) and two were gram negative i.e. Escherichia coli (ATCC 15224), and Enterobacter aerogenes (ATCC 13048). $100 \mu \mathrm{L}$ of 24 hours old bacterial cultures in nutrient broth were spread over Petri dishes $(7 \mathrm{~cm})$ containing $25 \mathrm{~mL}$ solidified nutrient agar. Sterile filter paper discs (diameter $6 \mathrm{~mm}$ ) impregnated with $100 \mu \mathrm{L}$ of extract dilutions $(1,5$ and $10 \mathrm{mg} / \mathrm{mL}$ DMSO) were placed over each of the culture plates. The plates were then incubated at $37^{\circ} \mathrm{C}$ for 24 hours. The anti-bacterial activity was determined by measuring zones of inhibition around the discs in each plate. Paper discs impregnated with $100 \mu \mathrm{L}$ of a solution of $2 \mathrm{mg} / \mathrm{mL}$ of Cefixime (Cef) were used as positive control while DMSO was used as negative control. The test was performed in triplicate and the mean standard deviation was calculated.

Antifungal assay. The antifungal assay was performed according to the methodology of $[27,28]$. The antifungal activity was studied against five fungal strains namely Mucor species (FFBP 0300), Aspergillus niger (FFBP 0198), Aspergillus flavis (FFBP 0064), Aspergillus fumigatus (FFBP 66) and Fusarium solani (FFBP 0291). All fungal strains were grown on $6.5 \%$ SDA (Sabouraud dextrose agar, $\mathrm{pH} 5.7$ ) at $28^{\circ} \mathrm{C}$ and preserved at $4^{\circ} \mathrm{C}$ in refrigerator. Terbinafine (Ter) $(200 \mu \mathrm{g} / \mathrm{mL})$ was used as standard drug while DMSO was used as negative control. Three concentrations of each of the extracts i.e. 1, 5 and $10 \mathrm{mg} / \mathrm{mL}$ DMSO were tested. SDA plates containing $25 \mathrm{~mL}$ medium were inoculated with $100 \mu \mathrm{L}$ fungal spores suspensions which was prepared by harvesting fungal spores' suspension in $2 \% \mathrm{w} / \mathrm{v}$ Tween 20 solution in distilled water and turbidity was adjusted to $0.5 \mathrm{McF}$ arland turbidity standards. Sterile filter paper discs (diameter $6 \mathrm{~mm}$ ) impregnated with $100 \mu \mathrm{L}$ of extract solution was placed over each of the culture plates. Inoculated plates were then incubated at $28^{\circ} \mathrm{C}$ for $24 \mathrm{~h}$ and zones of inhibition were measured in millimetres $(\mathrm{mm})$ around the each disc.

Antitumour Assay. Antitumour potato disc assay was performed by following the standard procedure as reported by [29]. A $48 \mathrm{~h}$ old culture of Agrobacterium tumefaciens strain was used to test the plant extracts. An inoculum of $1.5 \mathrm{~mL}$ containing six different concentrations of plant extracts $(10,000,1000,100$, 10 and $1 \mu \mathrm{g} / \mathrm{mL}$ ), bacterial cultures and distilled water was prepared. DMSO was used as negative control and vinblastine sulphate was used as positive control. Red skinned potatoes were surface sterilized by using $0.1 \% \mathrm{HgCl}_{2}$ solution followed by washing with distilled water three times. A borer of $8 \mathrm{~mm}$ diameter was used to dug out potato cylinders and cut into $4 \mathrm{~mm}$ discs. Autoclaved agar solution $(1.5 \% \mathrm{w} / \mathrm{v})$ was poured in Petri dishes $(20 \mathrm{~mL})$ and allowed to solidify. Ten discs were placed on agar surface of each Petri dishes and $50 \mu \mathrm{L}$ of inoculum was poured on the top of each disc. The plates were sealed with parafilm to avoid moisture loss and incubated at $28^{\circ} \mathrm{C}$ in dark. After 
21 days of incubation, potato discs were stained with Lugol's solution $\left(10 \% \mathrm{KI}, 5 \% \mathrm{I}_{2}\right)$, and tumours were counted under dissecting microscope. More than $20 \%$ tumour inhibition was considered significant. Tumour inhibition was calculated by using following formula:

$\%$ of tumour inhibition $=((1-\mathrm{Ts}) / \mathrm{Tc}) \times 100$,

where; "Ts" is Number of tumours in the sample and "Tc" is number of tumours in control.

Free radical scavenging activity. Free radical scavenging activity was measured by using 2,2, diphenyl-1picrylhydrazyl (DPPH) assay. DPPH free radical assay was performed according to the procedure described by [24]. The DPPH solution was prepared by dissolving $3.92 \mathrm{mg}$ in $100 \mathrm{~mL}$ of methanol. A volume of $2800 \mu \mathrm{L}$ of DPPH solution was added to glass vials followed by the addition of $200 \mu \mathrm{L}$ of plant extraction solution, leading to the final concentration of 1000, 500 and $100 \mu \mathrm{g} / \mathrm{mL}$. Mixtures were shaken well and incubated in dark at $37^{\circ} \mathrm{C}$ for $1 \mathrm{~h}$. Absorbance was measured at $517 \mathrm{~nm}$ by using a spectrophotometer (PDA 8453,

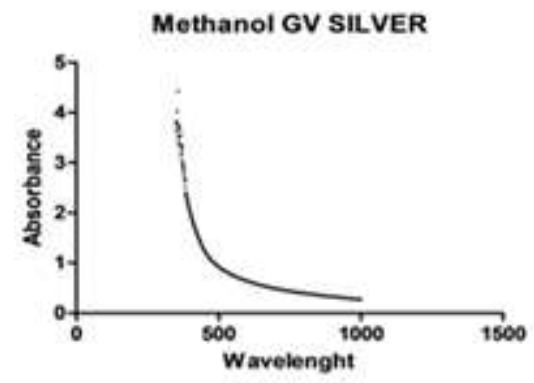

A

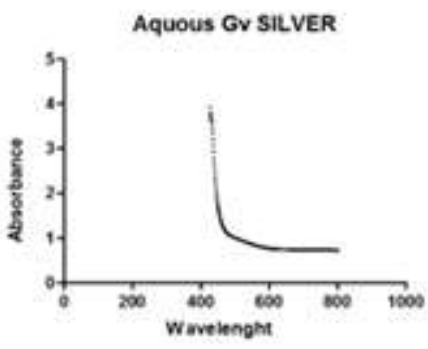

C

Agilent). DMSO was used as negative control and ascorbic acid (AsA) was used as positive control. Each test was performed in triplicate and percentage inhibition was measured according to the following formula:

$$
\% \text { scavenging effect }=((1-\mathrm{As}) / \mathrm{Ac}) \times 100,
$$

where; "Ac" is Absorbance of negative control and "As" is Absorbance of test sample.

\section{Results and Discussion}

The present study focused on the green synthesis of silver nanoparticles (AgNPs) from the root methanol, ethanol and aqueous extracts of M. alba.

Characterization of silver nanoparticles

Silver nanoparticles were successfully synthesized within three days from different extracts. After synthesis of silver nanoparticles, they were characterized by UV-Vis spectroscopy, X-ray diffraction analysis and SEM analysis.
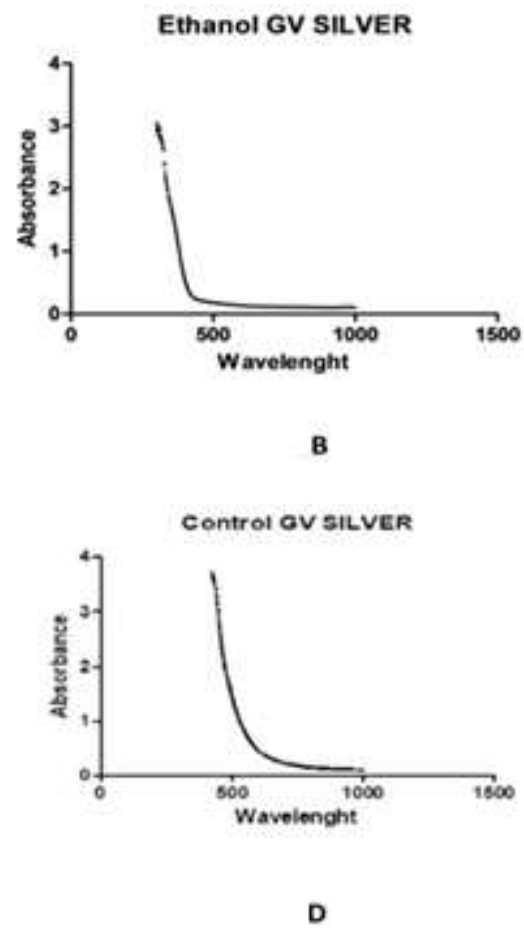

Figure 1.

UV-Vis peaks of silver nanoparticles obtained from different Morus alba extracts or control (A) $=$ methanol; $(\mathrm{B})=$ ethanol; $(\mathrm{C})=$ aqueous; $(\mathrm{D})=$ control

\section{$U V$-Vis spectroscopy}

The reduction of silver ions to AgNPs was observed when the plant extract was treated with $\mathrm{AgNO}_{3}$ (Figure 1 A-D). The peaks for silver nanoparticles were observed between $400 \mathrm{~nm}$ to $450 \mathrm{~nm}$ which are characteristic for silver nanoparticles. Absorption peaks of mulberry leaf extract were in the range of $380 \mathrm{~nm}$ to $800 \mathrm{~nm}$. The peaks of methanol, ethanol, aqueous and control extracts of silver nanoparticles were observed between 500 - $800 \mathrm{~nm}, 480$ - $800 \mathrm{~nm}$,
$450-800 \mathrm{~nm}, 500-800 \mathrm{~nm}$ respectively observed by UV-Vis spectroscopy.

\section{$X R D$ diffraction}

The crystalline nature of the silver nanoparticles was confirmed through the XRD method. The characteristic peak of silver nanoparticles in accordance to Miller Indices was obtained by the methanol extract (Figures 2 A-D). On the basis of the face-cantered cubic structure of silver the XRD pattern showed numbers of Bragg reflections. Peaks of XRD values 
were found at $20,25,30,35,40$ were observed to 121, 200, 210, 220 and 311 planes. X-ray diffraction results clearly showed that the silver nanoparticles

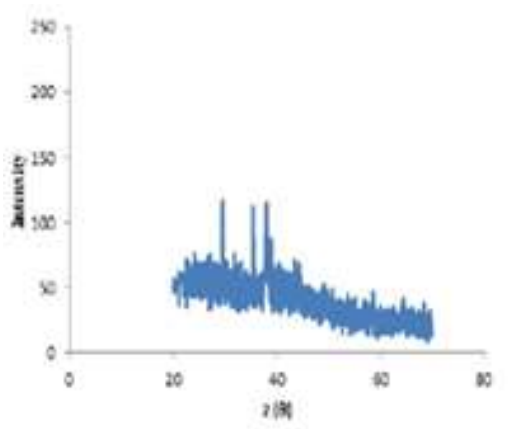

A

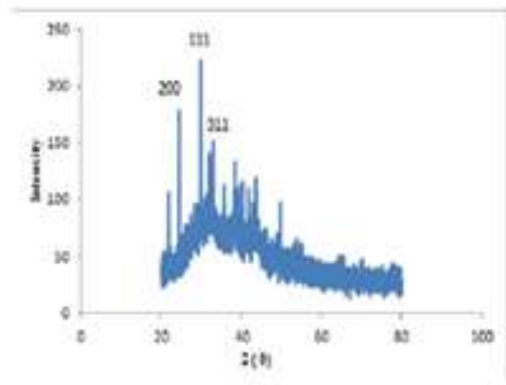

C formed by the reduction of $\mathrm{Ag}^{+}$ions by the Morus root extracts were crystalline in nature.

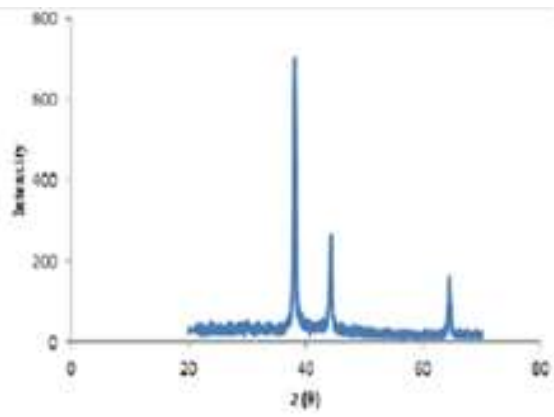

B

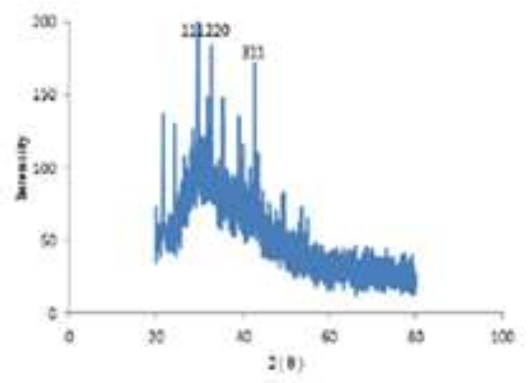

D

Figure 2.

Peaks of XRD values for silver nanoparticles obtained from different Morus alba extracts or control (A) = methanol; (B) = ethanol; (C) = aqueous; (D) = control

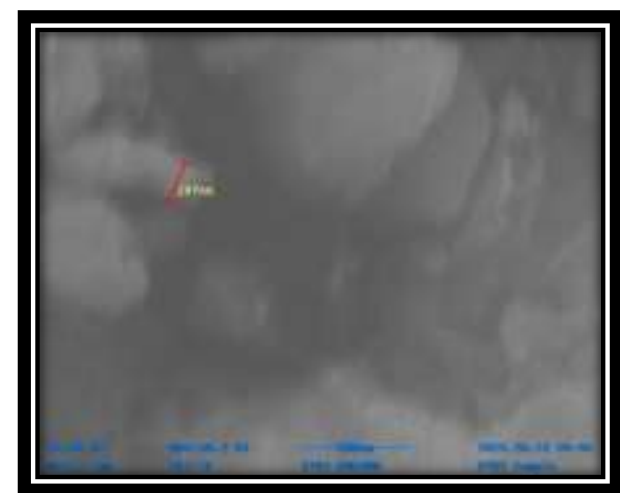

(A)

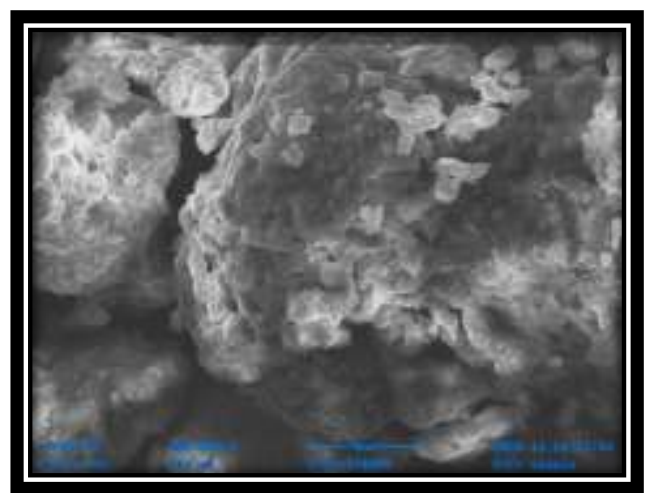

(B)

Figure 3.

SEM images of silver nanoparticles: $(A)=$ size of silver nanoparticles and $(B)=$ shape of silver nanoparticles

\section{SEM Analysis}

SEM has been used to assess the morphology and size of the silver nanoparticles synthesized. The nanoparticles were irregular in shape and their surface was rough. The size of silver nanoparticles was found to be $297 \mathrm{~nm}$ (Figure 3A and Figure 3B).

\section{Biological Activities}

Antibacterial activity. Nanoparticles synthesized from root extracts of $M$. alba showed significant anti- bacterial activities against the tested microorganisms. Among all extracts (methanol, ethanol and aqueous), the methanolic extract showed the strongest antibacterial activity with MIC value of 0.5 as compared to ethanolic extract $(\mathrm{MIC}=5)$ and aqueous extracts $(\mathrm{MIC}=10)$. Control fractions of all the extracts showed lower antibacterial activity i.e. methanol $(\mathrm{MIC}=10)$, ethanol $(\mathrm{MIC}=10)$ and aqueous $(\mathrm{MIC}=10)$ as compared to nanoparticles (Table II). 
Antibacterial activity of $M$. alba against bacterial strains

\begin{tabular}{|c|c|c|c|c|c|c|c|}
\hline \multirow[t]{2}{*}{ Plant } & \multirow[t]{2}{*}{ Extracts type } & \multirow[t]{2}{*}{ Samples } & \multicolumn{5}{|c|}{$\begin{array}{c}\text { Antibacterial Activity } \\
\text { MIC }(\mu \mathrm{g} / \mathrm{mL})\end{array}$} \\
\hline & & & S. aureus & B. subtilis & M. luteus & E. coli & E. aerogenes \\
\hline \multirow{8}{*}{ Morus alba } & \multirow{2}{*}{ methanol } & NP & 0.5 & 0.5 & 1 & 0.5 & 1 \\
\hline & & $\mathrm{C}$ & 10 & 10 & 10 & 10 & 10 \\
\hline & \multirow{2}{*}{ ethanol } & NP & 5 & 5 & 5 & 5 & 5 \\
\hline & & $\mathrm{C}$ & 10 & 10 & 10 & 10 & 10 \\
\hline & \multirow{2}{*}{ aqueous } & NP & 10 & 10 & 15 & 10 & 10 \\
\hline & & $\mathrm{C}$ & 15 & 15 & - & 10 & 15 \\
\hline & Post. Cont. & Cef. & 6 & 6 & 12 & 12 & 12 \\
\hline & Post. Cont. & Ter. & - & - & - & - & - \\
\hline
\end{tabular}

Cef = cefixime; Ter $=$ terbinafine $; \mathrm{C}=$ control extract; Post. Cont. $=$ positive control

Antifungal activity. All the nanoparticles synthesized from different extracts of Morus alba root showed strong antifungal activity against all fungal strains as compared to control fractions. Among all the extracts (methanol, ethanol and aqueous), the methanolic extract showed the strongest antifungal activity with MIC

value of 0.5 as compared to ethanolic extract $(\mathrm{MIC}=5)$ and aqueous extracts $(\mathrm{MIC}=10)$. Control fractions of all the extracts showed lower antifungal activity i.e. methanol $(\mathrm{MIC}=10)$, ethanol $(\mathrm{MIC}=10)$ and aqueous (MIC $=15)$ as compared to nanoparticles (Table III).

Table III

Antifungal activity of root extracts of $M$. alba against fungal strains

\begin{tabular}{|c|c|c|c|c|c|c|c|}
\hline \multirow[t]{2}{*}{ Plant } & \multirow[t]{2}{*}{ Extracts type } & \multirow[t]{2}{*}{ Samples } & \multicolumn{5}{|c|}{$\begin{array}{c}\text { Antifungal Activity } \\
\text { MIC }(\mu \mathrm{g} / \mathrm{mL})\end{array}$} \\
\hline & & & Mucor sp. & A. niger & A. flavis & A. fumigatus & F. solani \\
\hline \multirow{8}{*}{ Morus alba } & \multirow{2}{*}{ methanol } & NP & 0.5 & 0.5 & 0.5 & 0.5 & 1 \\
\hline & & $\mathrm{C}$ & 10 & 10 & 10 & 10 & 10 \\
\hline & \multirow[b]{2}{*}{ ethanol } & NP & 1 & 1 & 1 & 5 & 5 \\
\hline & & $\mathrm{C}$ & 10 & 10 & 10 & 10 & 10 \\
\hline & \multirow[b]{2}{*}{ aqueous } & NP & 10 & 10 & 10 & 10 & 5 \\
\hline & & $\mathrm{C}$ & 15 & 15 & 15 & 15 & 15 \\
\hline & Post. Cont. & Cef. & - & - & - & - & - \\
\hline & Post. Cont. & Ter. & 3 & 5 & 3 & 3 & 5 \\
\hline
\end{tabular}

Cef $=$ cefixime; Ter $=$ terbinafine C $=$ control extract; Post. Cont. = positive control

Antioxidant activity. The synthesized nanoparticles from aqueous roots extracts of $M$. alba showed highest antioxidant activity. The synthesized nanoparticles showed the strongest antioxidant activity as compared to the control extract. From all the extracts (methanol, ethanol and aqueous), the methanolic extract showed the strongest antioxidant activity with $\mathrm{IC}_{50}$ value of 158.68 as compared to the ethanolic extract $\left(\mathrm{IC}_{50}=\right.$ $227.75)$ and aqueous extract $\left(\mathrm{IC}_{50}=255.26\right)$. Control fractions of all the extracts showed lower antifungal activity i.e. methanol $\left(\mathrm{IC}_{50}=393.27\right)$, ethanol $\left(\mathrm{IC}_{50}=\right.$ 411.52) and aqueous $\left(\mathrm{IC}_{50}=483.19\right)$ as compared to nanoparticles (Figure 4).

Antitumour activity. Nanoparticles synthesized from different roots extracts of $M$. alba (ethanol, methanol and aqueous) showed strong antitumour activity. From all the extracts (methanol, ethanol and aqueous), the methanolic extract showed the strongest antitumour activity with a $\mathrm{IC}_{50}$ value of 105.03 as compared to the ethanolic extract $\left(\mathrm{IC}_{50}=115.58\right)$ and aqueous extract $\left(\mathrm{IC}_{50}=138.37\right)$. Control fractions of all the extracts showed lower antitumour activity i.e. methanol $\left(\mathrm{IC}_{50}=\right.$ $159.55)$, ethanol $\left(\mathrm{IC}_{50}=181.66\right)$ and aqueous $\left(\mathrm{IC}_{50}=\right.$ 288.12) as compared to nanoparticles (Figure 5).

Cytotoxicity activity. Nanoparticles synthesized from different roots extracts of $M$. alba (ethanol, methanol and aqueous) showed strong cytotoxic activity. Methanolic extract of M. alba showed a more significant cytotoxic effect. From all the extracts (methanol, ethanol and aqueous), the methanolic extract showed the strongest cytotoxic activity with $\mathrm{IC}_{50}$ value of 24.83 as compared to ethanolic extract $\left(\mathrm{IC}_{50}=31.62\right)$ and aqueous extracts $\left(\mathrm{IC}_{50}=39.18\right)$. Control fractions of all the extracts showed lower cytotoxicity activity i.e. methanol $\left(\mathrm{IC}_{50}=49.74\right)$, ethanol $\left(\mathrm{IC}_{50}=74.05\right)$ and aqueous $\left(\mathrm{IC}_{50}=57.07\right)$ as compared to nanoparticles as shown in (Figure 6). 


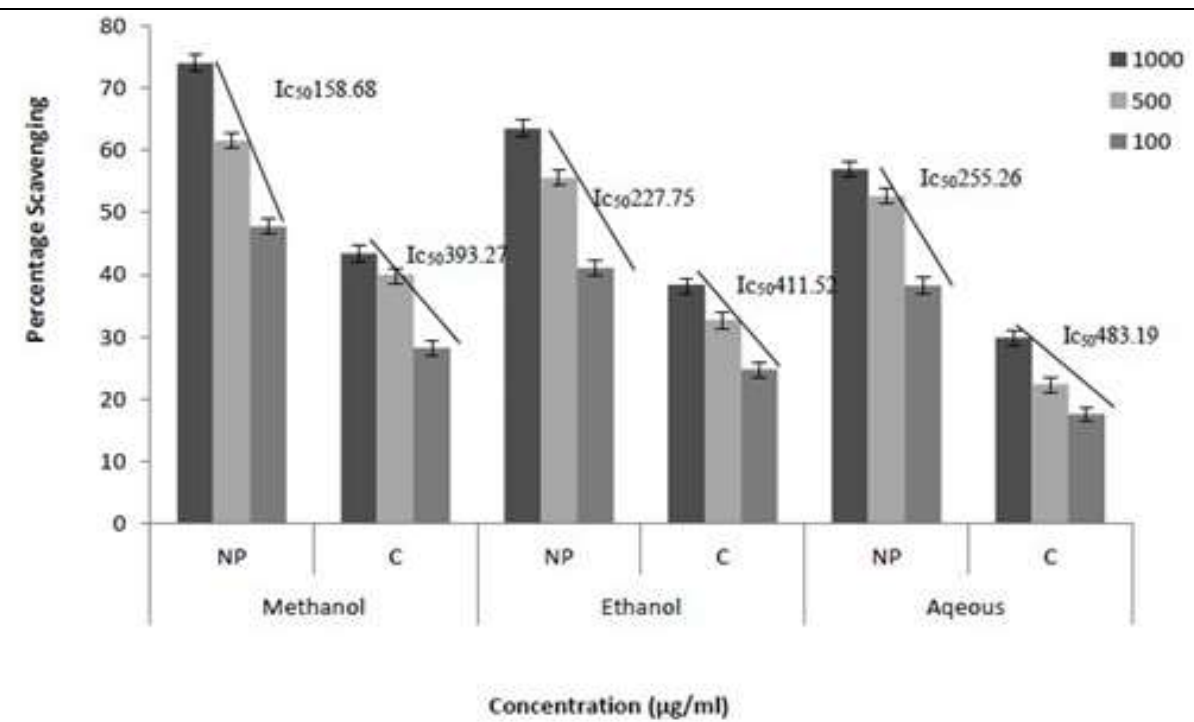

Figure 4.

$\mathrm{IC}_{50}$ values of antioxidant activity of nanoparticle from the methanol, ethanol and aqueous root extracts The data represents the mean values of three replicates together with the standard deviations shown as error bars.

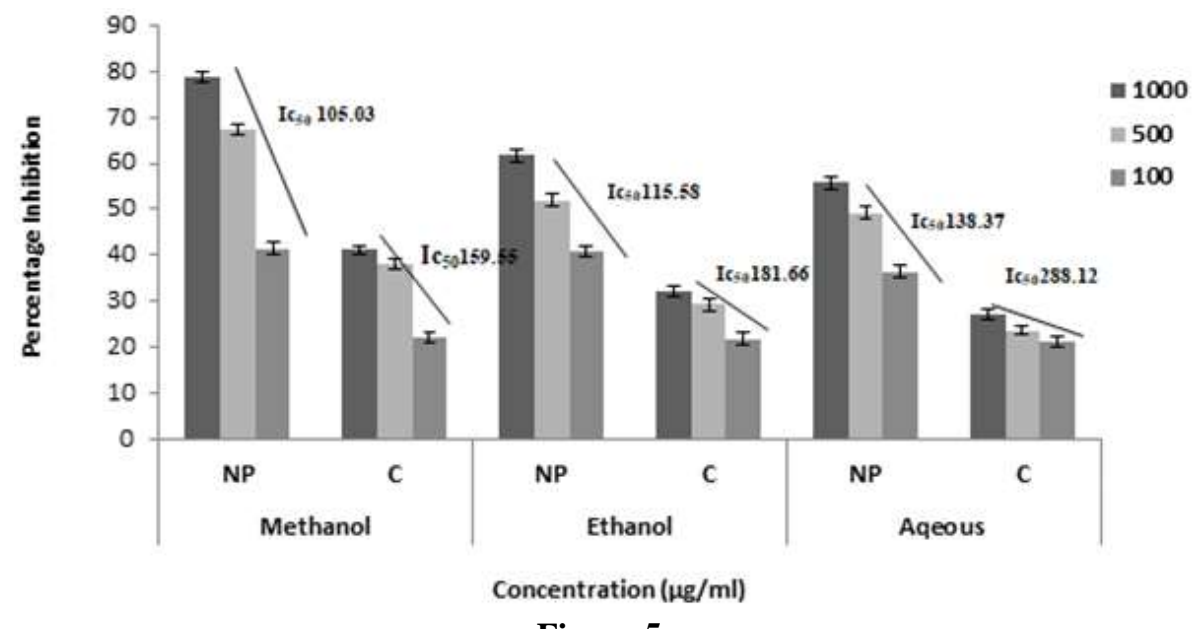

Figure 5.

$\mathrm{IC}_{50}$ values of antitumour activity of nanoparticle from the methanol, ethanol and aqueous root extracts The data represents the mean values of three replicates together with the standard deviations shown as error bars.

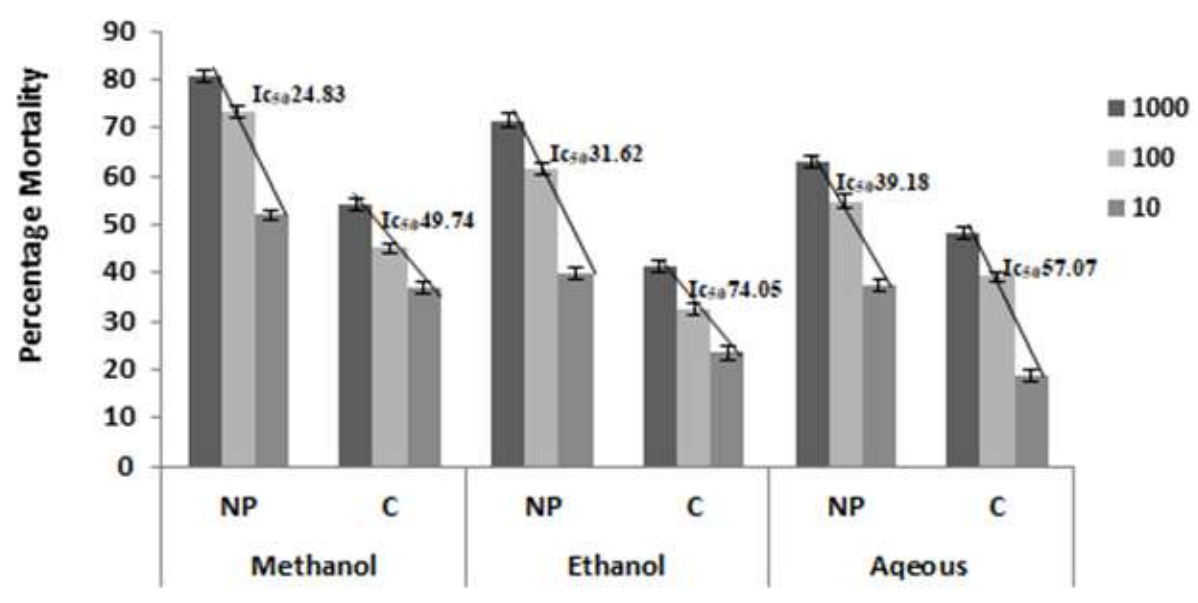

Concentration $(\mu \mathrm{g} / \mathrm{ml})$

Figure 6.

$\mathrm{IC}_{50}$ values of cytotoxic activity of nanoparticle from the methanol, ethanol and aqueous root extracts The data represents the mean values of three replicates together with standard deviations shown as error bars. 
Plants are a valuable source of natural products for maintaining human health. In history of all civilizations the use of medicinal plants for curing diseases has been recognized. For the medicinal property of the drugs the compounds that are responsible are usually secondary metabolites [30].

In recent years herbal medicines have gained importance due to their efficacy and low cost $[31,32]$. Pakistan has a varied climatic condition supporting the growth of nearly 6000 higher plant species of which nearly 12 percent plant species are reported for their medicinal value and the number is increasing constantly due to current interest of local researchers in natural products [6]. Medicinal compounds derived from plants have potential value and proposed as a tangible benefit of biodiversity and therefore a basis for promoting its conservation [33].

Different species of Morus are famous for their medicinal properties such as Morus alba (Mulberry) and Morus rubra. M. alba have strong antifungal, antioxidant, antitumour, nephroprotective, anti-HIV, antihyperglycaemic, skin tonic and neuroprotective activities [9]. Mulberry shows a resistance to pests and disease, and comparatively requires low costs for cultivation as compared to other plants. Plantations of mulberry provide a low utilization of degraded or productive agricultural land, and can be used to produce electricity, heat, gas and liquid fuel production, and are one of the most important sources of fibres [34].

The present work focused on green synthesis of silver nanoparticles from root extract of $M$. alba, due to its cost effectiveness, eco-friendly and medicinal properties. Green synthesis of nanoparticles is the current market demand due to environmentally friendly process and reduced production of hazardous matter [35]. Silver nanoparticles synthesis was indicated by colour changed from yellow to grey due to reduction of silver nanoparticles within 7 days. UV-Vis, XRD and SEM were used to characterize the silver nanoparticles. Characterization of synthesized silver nanoparticles was performed with slight modifications in the methodology of [2].

Stability and formation of AgNPs in methanol, ethanol and aqueous solution were confirmed by using UV-Vis spectroscopy (Figure 1 A-D). It is usually documented that UV-Vis spectroscopy could be used to examine the shape and size of nanoparticles [36]. The crystalline nature of silver nanoparticle was confirmed by X-ray diffraction dimension (Figure 2 A-D). Comparison of XRD spectrum with the standard confirmed that the silver particles formed in the form of nanocrystals, as evidenced by the peaks at 20,25, 30, 40 values corresponding to $111,220,311$ and these results are in accordance with the findings of literature [37]. Further confirmation of the silver nanoparticles synthesis was proved by the Scanning Electron Microscopy (SEM) which has shown the size as well as shape of the silver nanoparticles. The shape was found to be rough and the size was $297 \mathrm{~nm}$.

Bioassays have proved to be good tools for the biological evaluation of plant extracts and their nanoparticles. Crude botanical extracts comprised of very effective mixtures of bioactive compounds which can be analysed by simple bioassay procedures and various separation techniques [38]. In the present study, nanoparticles from different extracts (methanol, ethanol, aqueous) were prepared and evaluated for their biological activities like antimicrobial, cytotoxic, antioxidant and antitumour activities.

Brine shrimp cytotoxicity assay was a useful probe for the pharmacological activities in plant extracts [39]. In this study different fractions of $M$. alba roots extract were analysed as compared to control roots. All the nanoparticles from different extracts showed higher cytotoxic activities as compared to controls (Figure 5). Many prenylated flavonoids have been isolated from Morus indica root bark [40] and silver nanoparticles synthesized reported the strong cytotoxic activity.

In the antimicrobial assay, nanoparticles from all root extracts showed strong activities against all bacterial strains tested whereas control plant extract showed less antibacterial activities (Table II). Adavallan K et al. reported antibacterial activity of gold nanoparticles of $M$. alba, but there are no reported studies on antibacterial activity of silver nanoparticles so far [37]. The synthesized AgNPs from M. alba showed strong antifungal activity against all the tested fungal strains (Table III). This is the first report of antifungal activity of silver nanoparticles from M. alba. However, Hafez RA et al. reported antifungal activity of silver nanoparticles synthesized from Morus nigra [7]. The result suggests that silver nanoparticles from root extracts of $M$. alba can be a good source of antifungal products. It can serve as an increased plant antimicrobial defence and increased synthesis medicinally important secondary metabolites.

Antitumour potato disc assay is a valuable tool, which indicates the antitumour activity of test compounds. The present study revealed moderate to high degree of inhibition of tumour formation in case of all extracts tested (Figure 4). Silver nanoparticles presented significant inhibition of tumour formation especially the methanolic extracts showed the highest activity as compared to all other extracts (ethanol, aqueous). This is the first report of antitumour activity of silver nanoparticles of $M$. alba as there are no reported studies on antitumour activity.

The DPPH free radical scavenging assay was used to evaluate the antioxidant potential of the samples. This assay has been used for investigating antioxidant properties of wheat, vegetables, herbs, edible seed oils, conjugated linoleic acids, and flours by using different organic solvent systems including ethanol, aqueous acetone, methanol, aqueous alcohol 
and benzene [41-45]. It is a non-enzymatic method currently used to provide basic information about the ability of compounds to scavenge free radicals. Reduction of DPPH by an antioxidant results in the loss of absorbance at $517 \mathrm{~nm}$ [46]. Significant DPPH scavenging activity was observed in all synthesized silver nanoparticles from different extracts of $M$. alba (Figure 3). Silver nanoparticles synthesized from methanolic extracts showed more pronounced antioxidant activity compared to other extracts. Our results are in accordance with other published data [47]. These results suggest that secondary metabolites in the root extracts of $M$. alba may be responsible for this enhanced antioxidant activity.

\section{Conclusions}

The present study reported the simple and successful method for the synthesis of silver nanoparticles by using $M$. alba roots extract. Advantage of the synthesis of silver nanoparticles using $M$. alba root extracts is that it is efficient, economical, cost effective and environmentally friendly. The present study and data showed that silver nanoparticles from the root extract of $M$. alba was found to have best biological activities as compared to control extracts and secondary metabolites can be the cause for all these activities. The insight of this study has made possible in conclusion that nanoparticles synthesized from Morus alba plants can be used to treat multiple disease and meet the increasing demand of drug manufacturers for its multi pharmacological importance.

\section{Acknowledgement}

The authors are very thankful to the Higher education commission (HEC) Pakistan for supporting this work.

\section{Conflict of interest}

The authors declare no conflict of interest.

\section{References}

1. Parry J, Su L, Luther M, Zhou KQ, Yurawecz MP, Whittaker P, Yu LL, Fatty acid composition and antioxidant properties of cold-pressed marionberry, boysenberry, red raspberry, and blueberry seed oils. J Agric Food Chem., 2005; 53(3): 566-573.

2. Atanasov AG, Waltenberger B, Pferschy W, EvaMaria L, Thomas W, Christoph U, Pavel T, Veronika W, Schwaiger L, Stefan H, Elke H, Rollinger N, Judith M, Schuster D, Breuss Q, Johannes M, Bochkov V, Mihovilovic MD, Brigitte B, Rudolf D, Verena M, Stuppner H, Discovery and resupply of pharmacologically active plant-derived natural products: A review. Biotech Adv., 2015; 33(8): 1582-1614.

3. Jagessar RC, Mohamed A, Gomes G, An evaluation of the Antibacterial and Antifungal activity of leaf extracts of Momordica charantia against Candida albicans, Staphylococcus aureus and Escherichia coli. Nature Sci., 2008; 6(1): 1545-0740.
4. Makarov VV, Love AJ, Sinitsyna OV, Makarova SS, Yaminsky IV, Taliansky ME, Kalinina NO, Green Nanotechnologies: Synthesis of metal nanoparticles using plants. Acta Nat., 2014; 6(1): 35-44.

5. Ahmed S, Saiqa I, Silver nanoparticles: one pot green synthesis using Terminalia arjuna extract for biological application. J Nanomed Nanotech., 2015; 6(4): 309316.

6. Singh A, Shrivastava S, Sharma M, Sharma CK, Sangeeta $\mathrm{S}$, Biosynthesis and characterization of silver nanoparticles using Morus alba L. and their antioxidant activity. J Nanosci Nanotech., 2016; 320-320.

7. Hafez RA, Mosaad A, Abdel W, Ahmed FS, AlZahraa A, Karam E, Green synthesis of silver nanoparticles using Morus nigra leave extract and evaluation their antifungal potency on phytopathogenic fungi. J App Pharma Sci., 2017; 7(02): 041-048.

8. Raut RW, Kolekar NS, Lakkakula JR, Mendhulkar VD, Kashid SB, Photosynthesis of silver nanoparticles using Gliricidia sepium (Jecq.). Curr Nanosci., 2009; 5(1): 117-122.

9. Kumar R, Chauhan RS, Mulberry: Life enhancer. $J$ Medicin Plants Res., 2008; 2(10): 271-278.

10. Khalil A, Fouad H, Elsarnagawy T, Fahad N, Almajhdi $\mathrm{N}$, Preparation and characterization of electrospun PLGA/silver composite nanofibers for biomedical applications. Int J Electrochem Sci., 2013; 8(3): 34833493.

11. Kharissova L, Oxana V, Rasika D, Boris I, Kharisov C, Betsabee OP, Victor M, Jiménez P, The greener synthesis of nanoparticles. Trends Biotechnol., 2013; 31(4): 240-248.

12. Dey P, Chaudhuri TK, Pharmacological aspects of Nerium indicum Mill: A comprehensive review. Phco Rev., 2014; 8(16): 156-162.

13. Ansari, MA, Haris MK, Mohammad A, Mohammad J, Syed G, Ruchita P, Javed M, Green synthesis of $\mathrm{Al}_{2} \mathrm{O}_{3}$ nanoparticles and their bactericidal potential against clinical isolates of multi-drug resistant Pseudomonas aeruginosa. World J Microbiol Biotechnol., 2015; 31(1): 153-164.

14. Korbekandi H, Siavash I, Silver Nanoparticles. INTECH, 2012; Open Access Publisher.

15. Shakeel A, Mudsar A, Babu LS, Saiqa I, A review on plant extract mediate synthesis of silver nanoparticles for antimicrobial applications a green expertise. Department of Chemistry, Faculty of Natural Sciences, Jamia Milla Islamia, India, 2015.

16. Narayanan B, Kannan B, Natarajan S, Biological synthesis of metal nanoparticles by microbes. $A d v$ Col Interface Sci., 2010; 156(1): 1-13.

17. Garima M, Singh P, Verma, R, Kumar S, Srivastav S, Jha K, Khosa RL, Traditional uses, phytochemistry and pharmacological properties of Moringa oleifera plant: An overview. Der Pharmacia Lettre, 2011; 3(2): 141-164.

18. Nickavar B, Golboo M, Influence of Three Morus Species Extracts on $\alpha$-Amylase Activity. Iran $J$ Pharmaceut Res., 2010; 8(2): 115-119.

19. Shankar R, Lavekar GS, Deb S, Sharma BK, Traditional healing practice and folk medicines used by Mishing community of North East India. J Ayurveda Integ Med., 2012; 3(3): 124-129. 
20. Shinwari ZK, Medicinal plants research in Pakistan. J Medicin Plants Res., 2010; 4(3): 161-176.

21. Sarkar M, Kumbhakar R, Mitra A, Green synthesis of silver nanoparticles and its optical properties. Digest J Nanomat Biostruct., 2010; 5(2): 491-496.

22. Zafar M, Nephroprotective effects of Morus alba Linn. against Isoniazid induced toxicity in albino rabbits. 2012; M. Phil Thesis, Department of Physiology and Pharmacology, University of Agriculture Faisalabad, Pakistan.

23. Zhengyi W, Zhe-Kun Z, Michael G, Morus alba. eFloras, 2013; Missouri Botanical Garden, St. Louis, MO \& Harvard University Herbaria, Cambridge. M. Retrieved.

24. Huang DJ, Ou BX, Prior RL, The chemistry behind antioxidant capacity assays. J Agric Food Chem., 2005; 53(6): 1841-1856.

25. Finney DJ, A computer program for parallel line bioassays. J Pharmacol Exp Ther., 1976; 198(2): 497506.

26. Yen San Chan, Mashitah Mat Don, Biosynthesis and structural characterization of Ag nanoparticles from white rot fungi. Mat Sci Engin C., 2013; 33(1): 282-288.

27. Jane $S$, Green synthesis, characterization, and evaluation of the biological activities of silver nanoparticles synthesized from Morus indica (mulberry) fruit extract. World J pharm Pharmaceut Sci., 2017; 6(6): 12831301.

28. Haq IU, Mannan A, Ahmed I, Hussain I, Jamil M, Mirza B, Antibacterial activity and brine shrimp toxicity of Artemisia dubia extract. Pak J Bot., 2012; 44(4): 1487-1490.

29. Bibi G, Ullah N, Mannan A, Mirza B, Antitumor, cytotoxic and antioxidant potential of Aster thomsonii extracts. Afr J Pharm Pharmacol., 2011; 5(2): 252258.

30. Prior RL, Wu X, Schaich K, Standardized methods for the determination of antioxidant capacity and phenolics in foods and dietary supplements. J Agric Food Chem., 2005; 53(10): 4290-4302.

31. Sharma Hari S, Syed F, Saber M, John J, Aruna S, Influence of engineered nanoparticles from metals on the blood-brain barrier permeability, cerebral blood flow, brain edema and neurotoxicity. An experimental study in the rat and mice using biochemical and morphological approaches. J Nanosci Nanotech., 2009; 9(8): 5055-5072.

32. Fukumoto LR, Mazza G, Assessing antioxidant and prooxidant activities of phenolic compounds. J Agric Food Chem., 2000; 48(8): 3597-3604.

33. Pichersky E, Gang DR, Genetics and biochemistry of secondary metabolites in plants: an evolutionary perspective. Trends Plant Sci., 2000; 5(10): 439-445.

34. Yu LL, Free radical scavenging properties of conjugated linoleic acids. J Agric Food Chem., 2001; 49(7): 3452-3456.
35. Yogesh B, Yogeshkumar V, Sumitra C, Brine Shrimp Cytotoxicity, Anti-inflammatory and Analgesic Properties of Woodfordia fruticosa Kurz Flowers. Iran J Pharm Res., 2012; 11(3): 851-861.

36. Wan X, Lei M, Chen T, Tan Y, Yang J, Safe utilization of heavy-metal-contaminated farmland by mulberry tree cultivation and silk production. Sci Total Environ., 2017; 599-600: 1867-1873.

37. Adavallan K, Krishnakumar N, Mulberry leaf extract mediated synthesis of gold nanoparticles and its antibacterial activity against human pathogens. Adv Nat Sci Nanosci Nanotech., 2014; 5: 025018: 1-9.

38. Kaviya S. Santhanalakshmi B, Viswanathan G, Green synthesis of silver nanoparticles using Polyalthia longifolia leaf extract along with D-sorbitol: study of antibacterial activity. J Nanotech., 2011; 5(4): 233238.

39. Mittal J, Amla B, Abhijeet S, Madan M, Phytofabrication of nanoparticles through plant as nanofactories. $A d v$ Nat Sci., 2014; 5(4): 043002: 1-10.

40. Sasidharan S, Chen Y, Saravanan D, Sundram KM, Yoga L, Extraction, Isolation and Characterization of Bioactive Compounds from Plants' Extracts. Afr J Tradit Complement Altern Med., 2011; 8(1): 1-10.

41. Hussain J, Najeeb U, Abdul LK, Muhammad H. Murtaza H, Zabta KS, Proximate and essential nutrients evaluation of selected vegetables species from Kohat region, Pakistan. Pak J Botany, 2010; 42(4): 28472855.

42. Parveen S, Jan U, Kamili A, Importance of Himalayan medicinal plants and their conservation strategies. Aus J Herbal Med., 2013; 25(2): 63-67.

43. Rao M, Linga N, Savithramma A, Antimicrobial activity of silver nanoparticles synthesized by using stem extract of Svensonia hyderobadensis (Walp.) Mold - A rare medicinal plant. Res Biotech., 2012; 3(3): 12-17.

44. Zhou KQ, Yin JJ, Yu LL, Phenolic acid, tochopherol and carotenoid compositions, and antioxidant functions of hard red winter wheat bran. J Agr Food Chem., 2005; 53(10): 3916-3922.

45. Ulug BM, Haluk T, Ahmet C, Ahmet M, Role of irradiation in the green synthesis of silver nanoparticles mediated by fig (Ficus carica) leaf extract. Spectrochim Acta A Mol Biomol Spectrosc., 2015; 135: 153-161.

46. Gan PP, Shi H, Yan H, Sam F, Green synthesis of gold nanoparticles using palm oil mill effluent (POME): a low-cost and eco-friendly viable approach. Bioresource Tech., 2012; 113: 132-135.

47. Panyala A, Nagender R, Eladia M, Josef H, Silver or silver nanoparticles: a hazardous threat to the environment and human health, Nanosci Nanotech., 2008; 6(3): 117-129. 